\title{
Prevalence of Antibodies to Toxoplasma gondii in Raccoons (Procyon lotor) From an Urban Area of Northern Virginia
}

Author(s): Katie Hancock, Lori A. Thiele, Anne M. Zajac , Francois Elvinger, and David S. Lindsay Source: Journal of Parasitology, 91(3):694-695. 2005.

Published By: American Society of Parasitologists

DOI: http://dx.doi.org/10.1645/GE-443R

URL: http://www.bioone.org/doi/full/10.1645/GE-443R

BioOne (www.bioone.org) is a nonprofit, online aggregation of core research in the biological, ecological, and environmental sciences. BioOne provides a sustainable online platform for over 170 journals and books published by nonprofit societies, associations, museums, institutions, and presses.

Your use of this PDF, the BioOne Web site, and all posted and associated content indicates your acceptance of BioOne's Terms of Use, available at www.bioone.org/page/terms_of_use.

Usage of BioOne content is strictly limited to personal, educational, and non-commercial use. Commercial inquiries or rights and permissions requests should be directed to the individual publisher as copyright holder. 


\section{Prevalence of Antibodies to Toxoplasma gondii in Raccoons (Procyon lotor) From an Urban Area of Northern Virginia}

Katie Hancock, Lori A. Thiele*, Anne M. Zajac, Francois Elvingert, and David S. Lindsay, Center for Molecular Medicine and Infectious Diseases, Department of Biomedical Sciences and Pathobiology, Virginia-Maryland Regional College of Veterinary Medicine, Virginia Tech, 1410 Prices Fork Road, Blacksburg, Virginia 24061-0342; *Oral Rabies Vaccine Program, Fairfax County Health Department, 10777 Main Street, Fairfax, Virginia 22030; †Department of Large Animal Clinical Sciences, Virginia-Maryland Regional College of Veterinary Medicine, Virginia Tech, Duck Pond Drive, Blacksburg, Virginia 24061-0442. e-mail: lindsayd@vt.edu

ABSTRACT: Raccoons (Procyon lotor) are intermediate hosts for Toxoplasma gondii, and clinical toxoplasmosis in raccoons has been reported. A 2-yr serological survey was conducted to determine the prevalence of antibodies to $T$. gondii in raccoons collected from Fairfax County, Virginia, a suburban/urban area outside Washington, D.C. Serum samples from 256 raccoons were examined for $T$. gondii antibodies at a 1:50 dilution using the modified direct agglutination test. Results indicated that $216(84.4 \%)$ of the raccoons had been exposed to $T$. gondii. Our results indicate that raccoons in this area of Virginia are frequently exposed to $T$. gondii. Domestic cats were common in the study area and may have served as a source of oocysts for raccoons and the food items of raccoons.

Raccoons (Procyon lotor) can serve as environmental monitors for several zoonotic diseases of humans (Bigler et al., 1975). Because they are omnivores, raccoons can acquire Toxoplasma gondii infections by ingesting oocysts from the environment or tissue cysts within infected prey or scavenged food sources. Clinical toxoplasmosis has been observed in naturally infected raccoons (Maurer and Nielsen, 1981). Raccoons with concurrent canine distemper virus infection are more likely to have toxoplasmosis than are those without this immunosuppressive virus (Moller and Nielsen, 1964; Maurer and Nielsen, 1981; Dubey et al., 1992). The present study was conducted to determine the serological prevalence of antibodies to $T$. gondii in raccoons from an urban area of northern Virginia.

The raccoons used in the present study originated in various locations

TABLE I. Prevalence of antibodies to Toxoplasma gondii in raccoons.

\begin{tabular}{|c|c|c|c|}
\hline Location & $\begin{array}{l}\text { No. examined/ } \\
\text { No. positive } \\
(\%)\end{array}$ & Test* & Reference \\
\hline California & $25 / 12$ & IHAT & Franti et al. (1976) \\
\hline California & (29) & IHAT & Riemann et al. (1975) \\
\hline Florida & $530 / 95 \quad(18)$ & IHAT & Burridge et al. (1979) \\
\hline Florida & $24 / 7$ & MAT & Lindsay et al. (2001) \\
\hline Georgia & $67 / 22$ & DT & Walton and Walls (1964) \\
\hline Illinois & $379 / 184(49)$ & MAT & Mitchell et al. (1999) \\
\hline Iowa & $885 / 134(15)$ & MAT & Hill et al. (1998) \\
\hline Iowa & $30 / 20 \quad(67)$ & MAT & Dubey et al. (1992) \\
\hline Iowa & $14 / 4$ & MAT & Smith et al. (1992) \\
\hline Maryland & $77 / 18$ & DT & Jacobs and Stanley (1962) \\
\hline Massachusetts & $25 / 23$ & MAT & Lindsay et al. (2001) \\
\hline New Jersey & $45 / 33$ & MAT & Dubey et al. (1992) \\
\hline New Jersey & $25 / 10$ & MAT & Lindsay et al. (2001) \\
\hline Ohio & $119 / 67$ & MAT & Dubey et al. (1992) \\
\hline Pennsylvania & $93 / 45$ & MAT & Dubey et al. (1992) \\
\hline Pennsylvania & $25 / 6$ & MAT & Lindsay et al. (2001) \\
\hline South Carolina & $72 / 25 \quad(35)$ & MAT & Dubey et al. (1992) \\
\hline Virginia & $68 / 25$ & MAT & Dubey et al. (1992) \\
\hline Virginia & $256 / 216(84)$ & MAT & Present study \\
\hline
\end{tabular}

* DT, Sabin-Feldman dye test; IHAT, indirect hemagglutination test; MAT, modified direct agglutination test. of Fairfax County $\left(38^{\circ} 42^{\prime} \mathrm{N}, 77^{\circ} 10^{\prime} \mathrm{W}\right)$, Virginia, a suburban/urban area outside Washington, D.C. The animals were live-trapped as part of a larger study of rabies in Fairfax County. Blood samples were collected from all trapped raccoons. The animals were released immediately after sampling was completed. The serum was collected, placed in a tube, and frozen at $-70 \mathrm{C}$. Frozen sera were sent to the Center for Molecular Medicine and Infectious Diseases, Department of Biomedical Sciences and Pathobiology, Virginia-Maryland Regional College of Veterinary Medicine, Virginia Tech, Blacksburg, Virginia, for agglutination testing.

The modified direct agglutination test (MAT) (Dubey and Desmonts, 1987) was used to examine sera for agglutinating antibodies to $T$. gondii. The MAT has been validated in raccoons experimentally infected with T. gondii (Dubey et al., 1993). A dilution of 1:50 was used to screen sera in the present study. We examined serum samples from 136 raccoons in the year 2000 and from another 120 in the year 2001. Positive raccoon sera from the 2001 sampling period were examined further at dilutions of 1:500 and 1:1,000.

Positive MAT test results were found in 110 (80.9\%) of 136 raccoons from the year 2000 and in $106(88.3 \%)$ of 120 raccoons from the year 2001. Total prevalence over the 2 -yr study period was 216 of 256 $(84.4 \%)$. Thirty-six $(34.0 \%)$ of 106 positive samples from 2001 were MAT positive at a 1:500 dilution, and $31(29.2 \%)$ of these 106 samples also were positive at a 1:1,000 dilution.

Our overall prevalence is higher than that reported by others for raccoons from Virginia and other regions of the United States (Table I). This may result from the higher sensitivity and specificity of the MAT compared to those of other serological tests used to determine the prevalence of T. gondii. Dubey et al. (1993) evaluated the performance of the MAT, Sabin-Feldman dye test (DT), latex agglutination test (LAT), and indirect hemagglutination test (IHT) using sera from experimentally infected raccoons. They found that the MAT detected antibodies earlier and at higher titers compared with the other serological tests (Dubey et al., 1993). Results of the DT and MAT were similar for identifying positive raccoons, whereas the LAT and IHT gave consistently fewer positive titers (Dubey et al., 1993).

Raccoons are susceptible to both T. gondii tissue cysts and oocysts, but clinical toxoplasmosis has not been reported in experimentally infected raccoons (Miller et al., 1972; Dubey et al., 1993). Tissue cysts of experimentally infected raccoons are more prevalent in the muscles than in the brain (Dubey et al., 1993). This is interesting, because clinical toxoplasmosis in raccoons is associated with encephalitis and immunosuppression (Moller and Nielsen, 1964; Maurer and Nielsen, 1981; Dubey et al., 1992).

We did not catch bobcats (Lynx rufus) during our trapping of raccoons, but we frequently caught domestic cats. We estimate that we trapped $10-15$ cats for every 100 raccoons. Domestic cats are a probable source of $T$. gondii oocysts for raccoons and prey items of raccoons.

This study was supported in part by the County of Fairfax Board of Supervisors, Fairfax, Virginia, and by a clinical research grant from the Virginia-Maryland Regional College of Veterinary Medicine to D.S.L.

\section{LITERATURE CITED}

Bigler, W. J., J. H. Jenkins, P. M. Cumbie, G. L. Hoff, and E. C. Prather. 1975. Wildlife and environmental health: Raccoons as indicators of zoonoses and pollutants in southeastern United States. Journal of the American Veterinary Medical Association 167: 592 597. 
Burridge, M. J., W. J. Bigler, D. J. Forrester, and J. M. Hennemann. 1979. Serologic survey for Toxoplasma gondii in wild animals in Florida. Journal of the American Veterinary Medical Association 175: 964-967.

Dubey, J. P., And G. Desmonts. 1987. Serological responses of equids fed Toxoplasma gondii oocysts. Equine Veterinary Journal 19: 337-339.

- A. N. Hamir, C. A. Hanlon, and C. E. Rupprecht. 1992. Prevalence of Toxoplasma gondii infection in raccoons. Journal of the American Veterinary Medical Association 200: 534-536. S. K. Shen, P. Thulliez, and C. E. Rupprecht. 1993. Experimental Toxoplasma gondii infection in raccoons (Procyon lotor). Journal of Parasitology 79: 548-552.

Franti, C. E., H. P. Riemann, D. E. Behymer, D. Suther, J. A. HoWARTH, AND R. RUPPANNER. 1976. Prevalence of Toxoplasma gondii antibodies in wild and domestic animals in northern California. Journal of the American Veterinary Medical Association 169: 901906.

Hill, R. E., J. J. Zimmerman, R. W. Wills, S. Patton, and W. R. Clark. 1998. Seroprevalence of antibodies against Toxoplasma gondii in free-ranging mammals in Iowa. Journal of Wildlife Diseases 34: 811-815.

Jacobs, L., AND A. M. Stanley. 1962. Prevalence of Toxoplasma antibodies in rabbits, squirrels, and raccoons collected in and near the Patuxent Wildlife Research Center. Journal of Parasitology 48: 550. Lindsay, D. S., J. Spencer, C. Rupprecht, and B. L. Blagburn. 2001.
Prevalence of agglutinating antibodies to Neospora caninum in raccoons, Procyon lotor. Journal of Parasitology 87: 1197-1198.

Maurer, K. E., AND S. W. Nielsen. 1981. Neurologic disorders in the raccoon in northeastern United States. Journal of the American Veterinary Medical Association 79: 1095-1098.

Miller, N. L., J. K. Frenkel, AND J. P. Dubey. 1972. Oral infections with Toxoplasma cysts and oocysts in felines, other mammals, and in birds. Journal of Parasitology 58: 928-937.

Mitchell, M. A., L. L. Hungeford, C. Nixon, T. Esker, J. Sullivan, R. Koerkenmeier, and J. P. Dubey. 1999. Serologic survey for selected infectious disease agents in raccoons from Illinois. Journal of Wildlife Diseases 35: 347-355.

Moller, T., AND S. W. NiElsen. 1964. Toxoplasmosis in distemper susceptible carnivora. Veterinary Pathology 1: 189-203.

Riemann, H. P., J. A. Howarth, R. Ruppanner, C. E. Franti, and D. E. BEHYMER. 1975. Toxoplasma antibodies among bobcats and other carnivores of northern California. Journal of Wildlife Diseases 11: $272-276$.

Smith, K. E., J. J. Zimmerman, S. Patton, G. W. Beran, and H. T. HILL. 1992. The epidemiology of toxoplasmosis on Iowa swine farms with an emphasis on the roles of free-living mammals. Veterinary Parasitology 42: 199-211.

Walton, B. C., AND K. W. Walls. 1964. Prevalence of toxoplasmosis in wild animals from Fort Stewart, Georgia, as indicated by serological tests and mouse inoculation. American Journal of Tropical Medicine and Hygiene 13: 530-533.

\section{Toxoplasmosis in a Hawaiian Monk Seal (Monachus schauinslandi)}

Shelley P. Honnold, Robert Braun*, Dana P. Scott, C. Sreekumar + , and J. P. Dubey $\dagger \neq$, Armed Forces Institute of Pathology, Department of Veterinary Pathology, Washington, District of Columbia 20306-6000; *National Marine Fisheries, 2570 Dole Street, Honolulu, Hawaii; †Animal Parasitic Diseases Laboratory, Animal and Natural Resources Institute, Beltsville Agricultural Research Center, United States Department of Agriculture, Beltsville, Maryland 20705-2350. ‡To whom correspondence should be addressed. e-mail: jdubey@anri.barc.usda.gov

ABSTRACT: Toxoplasma gondii infection in marine mammals is intriguing and indicative of contamination of the ocean environment with oocysts. T. gondii was identified in a Hawaiian monk seal (Monachus schauinslandi) that had visceral and cerebral lesions. Tachyzoites were found in the lymph nodes, spleen, diaphragm, heart, adrenal glands, and brain. A few tissue cysts were found in sections of the cerebrum. The diagnosis was confirmed serologically, by immunohistochemical staining with $T$. gondii-specific polyclonal rabbit serum, and by the detection of $T$. gondii DNA. The genotype was determined to be type III by restriction fragment length polymorphisms of the SAG2 gene. This is the first report of $T$. gondii infection in a Hawaiian monk seal.

Toxoplasma gondii infections have been reported in many homeothermic animals, including several species of marine mammals (Dubey and Beattie, 1988; Resendes et al., 2002; Dubey et al., 2003). Recently, concerns have been raised that $T$. gondii may be a cause of mortality in sea otters, which are an endangered species in U.S. waters (Thomas and Cole, 1996; Lindsay et al., 2001; Miller, Gardner, Kreuder et al., 2002). Viable T. gondii was isolated from 15 of 67 (Cole et al., 2000) and 24 of 75 (Miller, Gardner, Packham et al., 2002) dead sea otters, indicating that $T$. gondii infection is common in this animal. It has been suggested that sea otters become infected with $T$. gondii oocysts in the sea from freshwater coastal runoff (Miller, Gardner, Kreuder et al., 2002). The Hawaiian monk seal (Monachus schauinslandi) is an endangered pinniped in U.S. waters and its population has declined since 1950. We report fatal $T$. gondii infection in this host for the first time.

An adult male Hawaiian monk seal (RK07) was found dead in the surf zone on 22 January 2004 at Otsuka beach on the east side of the island of Kauai, near the town of Kapaa. The animal was covered with ice, and a necropsy examination was performed $15 \mathrm{hr}$ later. This animal was in good nutritional condition as evidenced by normal blubber thick- ness. The submandibular, prescapular, and tracheobronchial lymph nodes were enlarged and darker than normal. The cranial lung lobes were edematous, glistening, and gelatinous bilaterally. The stomach contained $2 \mathrm{~L}$ of fluid, and the bile duct was enlarged. Helminths were found in the trachea and stomach.

Tissue specimens were fixed in $10 \%$ formalin and submitted to the Armed Forces Institute of Pathology, Washington, D.C., for histologic examination. Tissues were processed routinely, sectioned, stained with hematoxylin and eosin, and examined microscopically.

Tissues were also forwarded to the Animal Parasitic Diseases Laboratory, Beltsville, Maryland, for T. gondii examination. Deparaffinized sections of tissues were stained immunohistochemically with $T$. gondii and Neospora caninum polyclonal sera as described (Lindsay and Dubey, 1989; Dubey et al., 2001). In addition, sections were allowed to react with anti-BAG1 polyclonal rabbit antibody specific for bradyzoites (McAllister et al., 1996). A sample of frozen blood was thawed, centrifuged, and the serum was tested for antibodies to $T$. gondii using the modified agglutination test (MAT) as described (Dubey and Desmonts, 1987). For molecular confirmation, DNA was extracted from the lymph nodes of the monk seal using a DNAeasy tissue kit (Qiagen, Valencia, California) according to the manufacturer's instructions. The DNA sample was tested for the amplification of the $T$. gondii-specific SAG2 fragments (Howe et al., 1997), along with positive and negative controls. The PCR products were electrophoresed in a $2 \%$ agarose gel with molecular weight standards. Genotype was determined by restriction fragment length polymorphisms (RFLP) of the SAG2 gene (Howe et al., 1997).

Prominent lesions were observed in multiple tissues (lymph nodes, spleen, adrenal glands, diaphragm, and brain), and characterized by necrosis with variable numbers of extracellular and intracellular protozoal tachyzoites. The most severe lesions were within the lymph nodes (Fig. 